\title{
THE EFFECT OF USING SOCIAL MEDIA TOWARDS STUDENTS' READING COMPREHENSION
}

\author{
Prima Gusti Yanti ${ }^{1}$, Fairul Zabadi ${ }^{2}$, Fauzi Rahman ${ }^{3}$ \\ Universitas Muhammadiyah Prof. Dr. HAMKA ${ }^{1}$, Badan Bahasa Kemendikbud ${ }^{2}$, Universitas Indraprasta PGRI ${ }^{3}$, Indonesia \\ Jalan Limau 2 Kebayoran Baru, South Jakarta, Indonesia \\ Corresponding Author: prima_gustiyanti@uhamka.ac.id
}

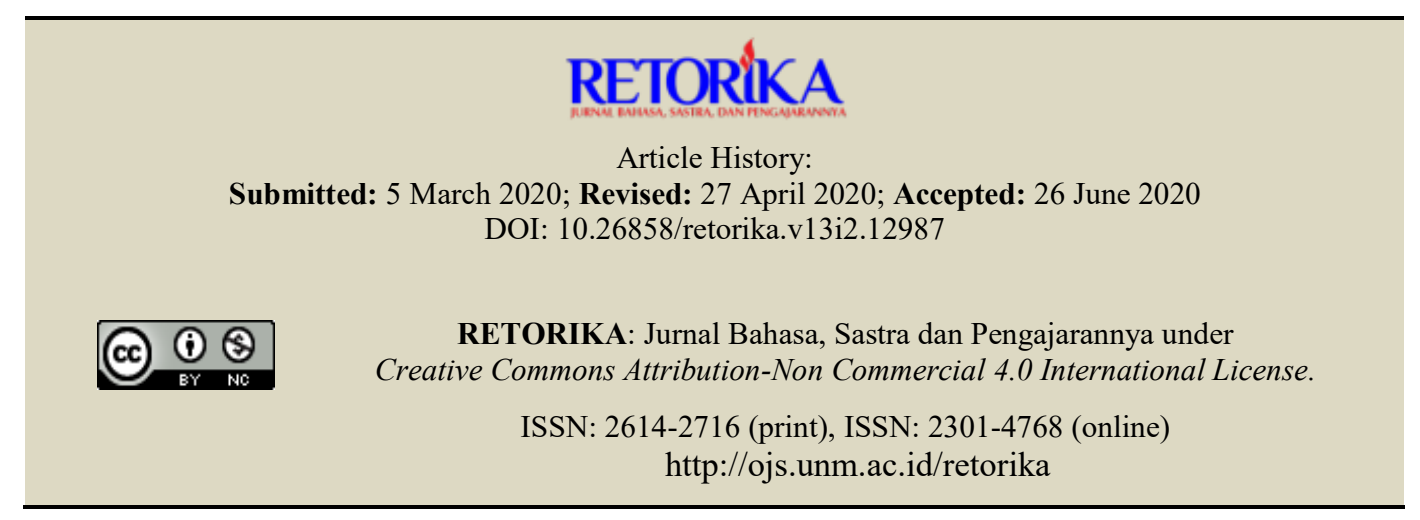

\begin{abstract}
This study aims to determine the effect of the activity of using social media on the ability of college students to reading comprehension. This type of research is quantitative with a correlational method. The sample in this study was taken with simple random sampling. PBSI FKIP UHAMKA active students approximately 600 students who if taken a sample of $25 \%$ at random, would choose 150 students. Data collection techniques using questionnaires and reading tests, while data analysis using descriptive statistics and simple linear regression equations. The results of this study indicate that the intensity of the use of social media in the percentage of students is $45 \%$ moderate, $25 \%$ low, $25 \%$ high, and $7 \%$ very high, obtained the regression equation $\hat{y}=68.945-$ $0.004 x$. These findings indicate that the more activity on social media, the lower the level of reading comprehension although not significantly.
\end{abstract}

Keywords: use of social media, college students, reading comprehension

In this era, social media has widely grown and appeared in various types, and it has become one of people's daily needs since it contains updated information and the latest news. In addition, social media can be utilized for many different purposes. It can increase people's income when it is used for business activities (Dewi, 2018). In relation to politics, social media can be used as a media that helps political parties in gaining people's awareness, increasing their participants, as well as delivering their aspirations or ideas
(Munzir, 2019). It is also applicable to measure population density problems (Susanti, 2015). Furthermore, some findings have revealed that social media has been operated to support teaching and learning activities (Moghavvemi et.al., 2018; Cassidy et.al, 2020; Mao, 2014; van Bommel. 2020). Thus, social media has been utilized in various fields, including education.

Having read some theorethical frameworks, the writer found an article related to a research conducted at SMPN 52 Surabaya in which 
they declared that the students were able to use social media wisely, for both educational and entertainment purposes even though most of the students have similar frequence in acsessing internet like teenagers in common. However, the writer has not yet found a research that is related to the use of social media and students' reading comprehension in particular (Sherlyanita \& Rakhmawati, 2016).

Therefore, the writer conducts this research in order to find out whether or not social media affects students' reading comprehension. In fact, to comprehend a reading text that has been read is really important to be achieved by anyone during reading activities. If there is no information collected or gathered into one's mind, reading activity is considered failed.

Moreover, reading comprehension is one of Bahasa Indonesia important skills that needs to be developed further among educational intitutions. Comprehension is a meaningful and willing process done by the readers in order to obtain information, message, and meaning from a reading text (Somadayo, 2015). Consequently, students do not only read, but also comprehend what they are reading. Hence, the most important thing is students are able to reflect what they have read, both in written and oral.

Lee, et.al (2013) explains that 4.0 industrial era can be identified from the improvement of digitalized manufactures driven by the increased data volume, computational power, and connectivity. These all can be seen from students' reading activities that is not solely rely on books anymore, but now shifting to electronic books or ebooks that are easily accessed throughout their smartphones. Recently, readers prefer to read online or search for electronic books instead of the printed ones.

Based on Media Planning Guide (2010), internet users (including the smartphone users) in Indonesia has increased drastically. This increase is dominated by youngsters around $60,7 \%$ (Susanto, 2011).

Furthermore, some studies related to reading comprehension through various non-virtual media, such as comics, illustrations, reading box, card games, have been conducted by many researchers (Martini, 2018; Siswati, 2012). It is in line with studies related to social media that has vulnerable or restricted content, so that teachers have to sort out things when using it for teaching and learning media (Bhattacharjee, Tolone,
Paranjape, 2019). The use of social media as a new platform in politics has also been conducted by some researchers. For example, a study by Rebecca Ping Yu (2016) that describes how social media behavior expresses politics. The use of social media in teaching and learning process has been conducted by Yanuarti dan Sari (2019) who explain how lecturers mostly utilize social media in classroom learning activities.

In fact, the writer has not found any studies that focus on the relationship between social media usage and students' reading comprehension. It is based on the assumption that almost all Indonesian students has gadgets ever since the 4.0 industrial era has been developing in Indonesia as well. Hence, gadget is no longer considered as luxurious thing, but now it becomes a tool to fulfill one's daily needs. In fact, internet users in Indonesia since Januari 2014 has reached 72,7 million. $98 \%$ has social media account and $79 \%$ has actively accessed social media account within last month. Another data confirmed that Facebook holds the biggest record with $93 \%$ of the total internet users in Indonesia (Endri, 2017: 9).

From the explanation stated above, it can be concluded that the research problem involves the relationship between reading comprehension and social media use among students of Pendidikan Bahasa dan Sastra Indonesia (PBSI), FKIP, UHAMKA. This research is focussing on the effect of using social media and one's reading comprehension. This article is elaborated with the assumption that the higher use of social media, the higher level of reading comprehension. Thus, this research is conducted in order to answer the above issue.

\section{METHOD}

This research is categorized as quantitative research using simple linear regression technique, that is to find relationship between independent variable $(\mathrm{X})$ toward dependent variable $(\mathrm{Y})$. The independent variable $(\mathrm{X})$ is intensity of using social media, while the dependent variable $(\mathrm{Y})$ is reading comprehension (Sugiyono, 2012; Arikunto, 2010).

The sampling technique used in this research was taken random and simple, called simple random sampling with the determination of a sample greater than 100 , that can be taken between $10 \%$ and $15 \%$ or $20 \%$ to $25 \%$ (Arikunto, 
2010). The sample was taken around $25 \%$ from the total population of active PBSI students of FKIP UHAMKA approximately 600 students, based on calculation formula $n=25 \% \times 600=150$ students, in which $\mathrm{n}$ (sample) and $\mathrm{N}$ (population). Meanwhile, the data was collected by using questionnaire.

The instruments used in this research are social media use activity and reading comprehension instruments. The social media use activity instrument cosists of 25 statement items using a Likert scale provided with 4 choices of answers ranging from always, often, sometimes, and never (Sugiyono, 2012), and the indicators are: (1) intensity of social media usage, (2) attachment to smartphones, (3) utilization of social media, and (4) writing criteria accessed on social media. In addition, reading comprehension instrument contains 10 question items using longer reading text along with review questions related to the reading text given.

Moreover, the instruments were tested for their validity and reliability by using Pearson Product Moment for the validity test and Cronbach's Aplha for the reliability test. The data was further computed by using Excel program by calculating the percentage of each statement item in each indicator, whereas SPSS 24 is used to calculate the regression equation and correlation continued with the t-test.

\section{FINDINGS AND DISCUSSION}

\section{Findings}

The findings will be explained through two stages: describing the survey result of social media use activity among students and the effect of using social media towards students' reading comprehension. In this case, the social media used are Facebook, Instagram, Whatsapp, Twitter, Line, dan Ask FM. This survey is needed in order to know the actual activities of students when using social media.

\section{The Survey of the Students' Social Media Use Activity}

In this case, the activities of using social media which are being observed further by the writers are: (1) Types of social media used; (2) duration of using social media; (3) reading short essay on social media; (4) reading long essay on social media.

\section{Types of Social Media Used}

Based on the survey result among PBSI students of UHAMKA, Instagram is the application with the most users. Almost all students of PBSI UHAMKA has Instagram account that reached $97 \%$ of the total percentage. Only $3 \%$ students do not have the account. The second highest application that has most users is Whatsapp with $96 \%$ of the total students. Line ranks next with $91 \%$ of total students, Facebook comes fourth with $69 \%$ users, Twitter with $68 \%$ and the last rank is Ask FM with only $9 \%$ users. The percentage of Instagram users can be seen in the following chart.

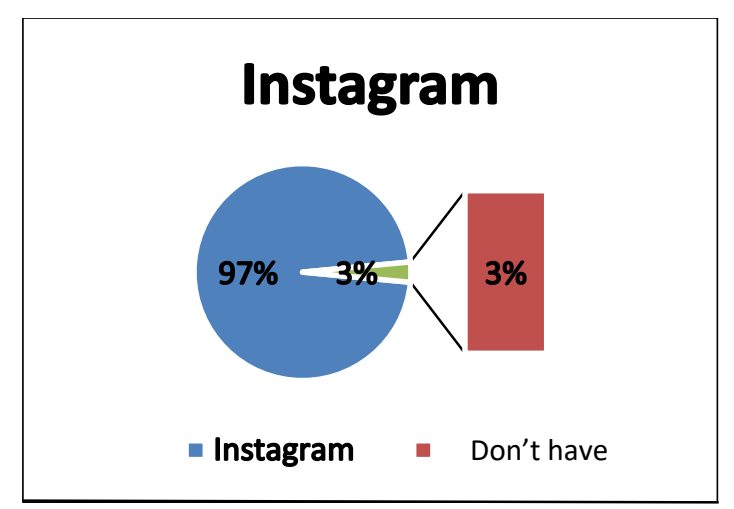

Figure 1. Survey Result of Instagram Users

After Instagram, the second highest percentage of social media applications is Whatsapp. Of all respondents, $96 \%$ of students are Whatsapp users. Only $4 \%$ of students do not have the application on a daily basis. This is solely based on the usefulness of Whatsapp application for daily communication purposes. Whatsapp is known as an effective media in exchanging messages both individually and in groups with varied features that are supportive and practical. The percentage of Whatsapp users can be seen in the following graph.

Besides Whatsapp, among UHAMKA PBSI Students, Line users are also numerous with a total of $91 \%$. In fact, there is an opinion claimed that Line is more convenient to use than Whatsapp. Normally, a Line user also uses Whatsapp in his/her social media activities. Whereas, the other $9 \%$ belongs to students who do not use the Line application. 


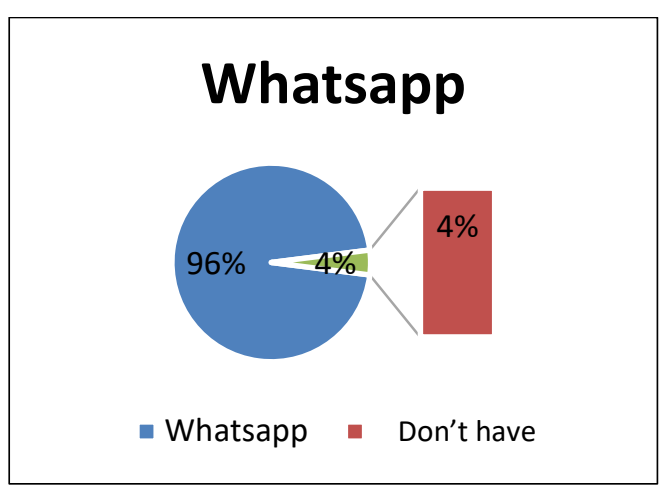

Figure 2. Survey Result of Whatsapp Users

Furthermore, facebook as a very wellknown application was not in the top rank, not even on the top three. Around 69\% of UHAMKA PBSI students have a Facebook account and actively use it. On the other hand, $31 \%$ of students do not have a facebook account.

After facebook, one of the most popular social media is Twitter. Through Twitter, a user can tweet (short sentences) in a timeline which can then be replied by others. Unlike Facebook in which users can create a whole composition, the characters set up in Twitter are very limited, only 140 characters for each tweet. However, Twitter users are quite numerous, it is used by many public figures such as actresses, actors, professional athletes, musicians, to politicians (Azeharie, 2016).

Among UHAMKA PBSI students, Twitter users are quite numerous, reaching $68 \%$ of users compared to $32 \%$ of non-users. It means the number of Twitter users among Uhamka PBSI students is almost similar to Facebook users (69\%). In fact, Facebook users usually have a Twitter account as well.

Finally, the social media Ask FM is the platform with the fewest users among UHAMKA PBSI students. Ask FM is a media where users can ask each other questions about certain information related to certain topics to other friends or even ask questions anonymously. Since the Ask FM feature is very limited, this social media is far less popular than Facebook, Twitter or Instagram. Even so, among UHAMKA PBSI students, only 9\% use this application; whereas, the remaining 91\% do not have accounts on Ask FM.

\section{Duration of Using Social Media}

The duration of using social media in a day refers to the intensity of a person in opening or accessing any social media, such as Facebook, Instagram, Twitter, Whatsapp, and others. Among UHAMKA PBSI students, it is known that around $43 \%$ of students or most of all respondents claimed to use social media as much as 5-8 hours a day (moderate). In addition, there are $25 \%$ of students who use social media between 1-4 hours (low), another 25\% use it for 9-12 hours (high), and there are $7 \%$ of students whose intensity in using social media is too high that is up to 13-15 hours a day (very high). The results of this survey can be grouped into these categories: $32 \%$ of social media use activities are very high, $43 \%$ are high, and low media use activity is just $25 \%$ which is between 1-4 hours. The duration of using social media can be seen in the following graph.

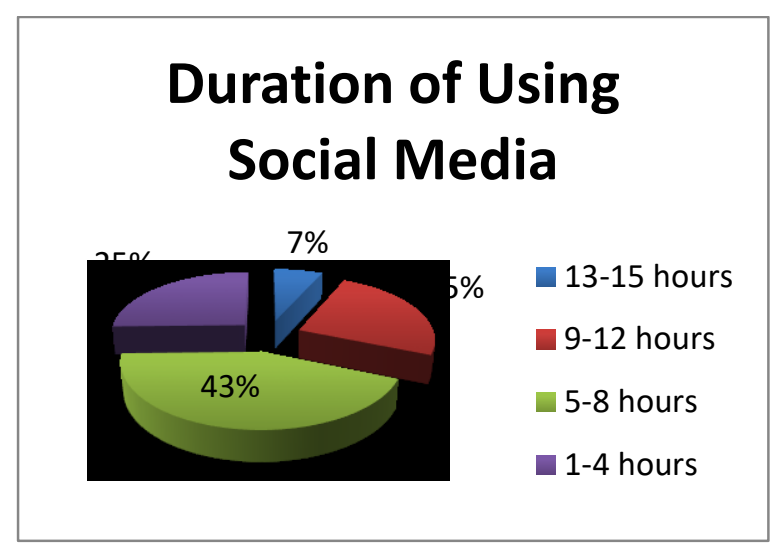

Figure 3. Duration of Using Social Media

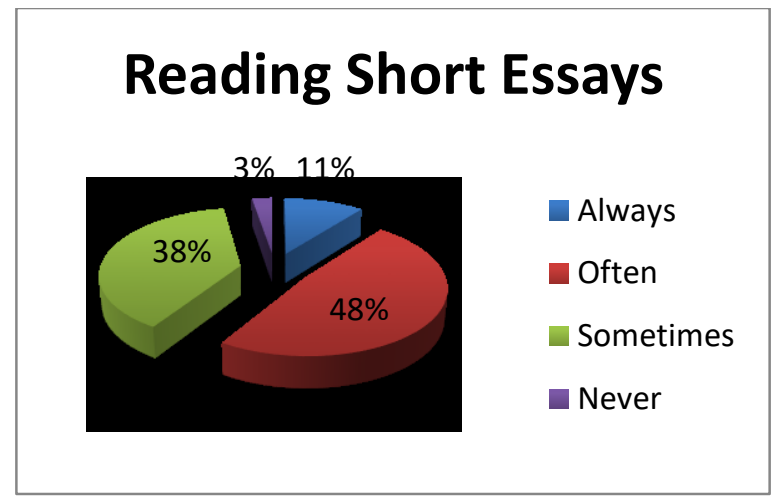

Figure 4. Survey Result of Reading Short Essays on Social Media

\section{Habits of Reading Short Essays on Social Media}

The habit of reading short essays for Uhamka PBSI students at a level of always that only gets a percentage of $11 \%$, often gets $48 \%$, sometimes with $38 \%$, and very rarely reading short essays as much as 3\%. It means that the habit of reading short essays for PBSI students of 
UHAMKA is $59 \%$ or falls in the medium category. This shows that students who are teenagers in the digital age prefer to see shorter forms of essay than longer essays. In relation to this digital era, teenagers also prefer writing with additional visual illustrations because it is more pleasing to read (Hidayat et al., 2019).

\section{Habits of Reading Long Essays on Social Media}

The habit of reading essays with long quantity of text mostly falls at a level of sometimes with a percentage of just over 54\%. Furthermore, students who frequently read long essays by $33 \%$, always $6 \%$, and students who rarely read long essays by $7 \%$. Based on this indicator, the reading habits of PBSI students on long essays are still unsatisfactory since they only achieve a percentage score of $39 \%$ or in the poor category. The habit of reading long essays on electronic devices (gadgets) is low because it requires excellent eye resistance. The longer one staring at the screen, especially the reading text, the more tired his/her eyes become which later on bring an impact on the cessation of reading activities (Indriastuti, 2019).

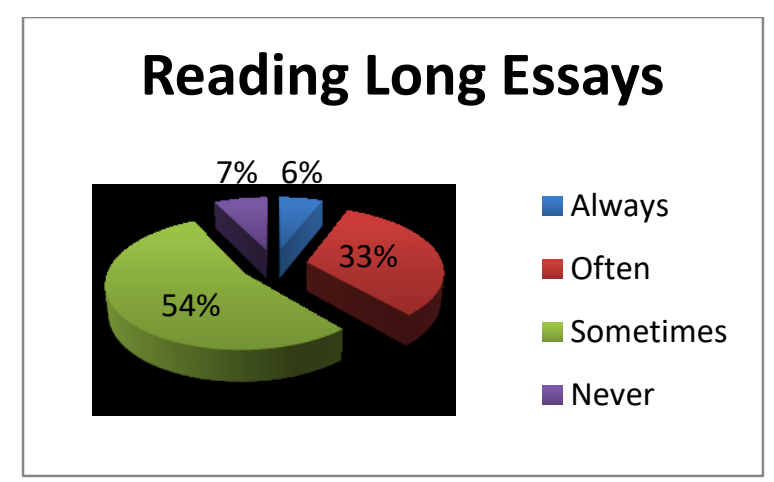

Figure 5. Survey Result of Reading Long Essays on Social Media

\section{Descriptive Statistics of Variables in the Use of Social Media Activities}

Statistical data on the use of social media variables among PBSI students shows the following data:

a. The smallest score of social media users is 48 out of the 10-100 score range, which means there are students whose social media activities are very minimal.

b. The biggest score of social media users is 92 out of the range of 10-100, which means that there are students who spend most of their daily activities actively on social media.

c. The average score of social media users among PBSI students of Uhamka was 68.66, or in the medium category.

d. The standard deviation or distribution of sample data on the variable of using social media is at a value of 8.79 meaning that the data distribution is not widely spread.

\section{Descriptive Statistics of Reading Comprehen- sion Variables}

The reading comprehension test used was constructed in a form of multiple choice and short answer questions. The test was carried out around 30 minutes to 150 active students by using gadget, that is google form. Statistical data on the reading comprehension variable among PBSI students shows the following data:

a. The lowest score on the reading ability test is 40.00 from the range of 10-100, which means there are students who have low reading comprehension ability.

b. The highest value of the reading ability test results is 90.00 from the range of $10-100$, which means there are students who have high level of reading comprehension abilities.

c. The average score of students on the reading ability test is 68.66 .

d. The standard deviation of the reading ability test variable is 11.33 .

\section{Simple Linear Regression Equation}

\begin{tabular}{|c|c|c|c|c|c|}
\hline \multicolumn{6}{|c|}{ Coefficients $^{\mathrm{a}}$} \\
\hline & $\begin{array}{l}\text { Unstand } \\
\text { Coeffici }\end{array}$ & lard. & $\begin{array}{l}\text { Stand- } \\
\text { ard.Coeff. }\end{array}$ & & \\
\hline Model & $\mathrm{B}$ & $\begin{array}{l}\text { Std. } \\
\text { Error }\end{array}$ & Beta & $\mathrm{t}$ & Sig. \\
\hline (Constant) & 68.945 & 7.334 & & 9.401 & .000 \\
\hline S_MED & -.004 & .106 & -.003 & -.038 & .970 \\
\hline
\end{tabular}

Based on the coefficient table above, there is a simple linear regression equation between the activities of using social media as variable $X$ and reading comprehension as variable $\mathrm{Y}$. This regression equation can be seen in column $\mathrm{B}$, with a constant value of 68,945 and $X$ coefficient of 0.004 . So, the regression equation becomes $\mathrm{y}^{\wedge}=$ 
$68,945-0.004 x$. The existence of a negative sign on the coefficient $\mathrm{x}$ that is -0.004 indicates that the regression is negative. This means that for every increase in one score of social media usage activity, reading comprehension will decrease by $68,945-0.004(1)=68,896$, or in other words, for every $1 \%$ increase in social media use activity, reading comprehension will be decreased by 0.004 .

\section{The Effect of Social Media Variables on Read- ing Comprehension}

\begin{tabular}{llccc}
\hline \multicolumn{5}{c}{ Model Summary $^{\mathbf{b}}$} \\
\hline \multirow{3}{*}{ Model } & $\mathrm{R}$ & R Square & Square & Estimate \\
\hline 1 & $\begin{array}{l}.003 \\
\mathrm{a}\end{array}$ & .000 & -.007 & 11.37005 \\
& & & \\
\hline
\end{tabular}

a. Predictors: (Constant), SOCIAL MEDIA

b.DependentVariable: READING ABILITY

The table model summary above in the $\mathrm{R}$ square column describes how social media influences students' reading ability, the $\mathrm{R}$ square value is 0.000 , which means that the use of social media does not bring any impact on reading comprehension.

Furthermore, to ascertain whether or not the regression coefficient is significant, the writer compared the sig value. With a probability value of 0.05 or by checking the t-count and t-table.

\begin{tabular}{|c|c|c|c|c|}
\hline \multicolumn{2}{|c|}{ Unstandardized Coefficients } & $\begin{array}{l}\text { Standardized } \\
\text { Coefficients }\end{array}$ & \multirow[b]{2}{*}{$\mathrm{T}$} & \multirow[b]{2}{*}{ Sig. } \\
\hline $\mathrm{B}$ & Std. Error & Beta & & \\
\hline 68.945 & 7.334 & & 9.401 & .000 \\
\hline-.004 & .106 & -.003 & -.038 & .970 \\
\hline
\end{tabular}

a. Dependent Variable:

READING ABILITY

Based on the coefficient table, sig. values are obtained around $0.970>0.05$. It means that the use of social media activities does not have any significantly effect on the reading comprehension ability of PBSI students of FKIP Uhamka.

Because the value of $t$-count $=$ $0.38<$ ttable $=1.96$, so it can be concluded that there is no significant impact of using social media towards the reading comprehension ability of PBSI students of FKIP UHAMKA.

\section{Discussion}

Activities of using social media among students are very diverse. However, it cannot be denied that social media has currently become part of people's daily life, especially students in their activities. Nowadays, social media is not just an entertainment media, but it has become communication and information tool that most people explored or searched for (Hindman, 2009; Rasul, Rahim, \& Salman, 2015).

Having seen the survey results of the use of social media among students, it was found that social media from the most users to the least one in sequence: Instagram reaching $97 \%$ of users, Whatsapp with a total of $96 \%$ of users, Line as much as $91 \%$ of total students, then Facebook with $69 \%$ of the total students, Twitter $68 \%$ of the total users, and finally Ask FM which is only owned by $9 \%$ of the total students.

At the beginning of social media outbreak in the community, especially in Indonesia, Facebook was a pioneer that held social media popularity at that time. However, over time, Instagram now becomes the most favorite social media compared to Facebook and Twitter.

The main reason why Instagram is on the top rank of social media popularity is due to its users who mostly come form public figure with million followers. This application is the most favorite one because of its features that are attractive (Chrismanto \& Lukito, 2017). Basically, this application is used to post photos or videos in the timeline of someone's account. However, Instagram has been developed steadily so that it can also be used for commercial purposes, such as advertising goods and services. The higher the followers of one's account, the more possible it is to make his/her account as a commercial account in order to get money (Miranda \& Lubis, 2017).

After Instagram, Whatsapp became the second most popular application among PBSI UHAMKA students. Currently, Whatsapp has even shifted the SMS (Short Message Service) feature which is the default application for a gadget. People in common, as well as students in particular, prefer Whatsapp to communicate daily with friends because of several advantages, such as: (1) no need to spend more credit, (2) able to create groups for multi-user interaction, (3) able to attach images, audio recordings, songs and vid- 
eos. These provided features can actually be accessed on SMS services (except group features) as well, including sending more multimedia messages, with an additional feature called Multimedia Message Service (MMS); however, it requires extra credit (Church \& De Oliveira, 2013).

Similar to Whatsapp, Line users are also at a high percentage, reaching $91 \%$ of all PBSI students of UHAMKA. Actually, the operating system of Line application is closely similar to Whatsapp compared to other applications. Line and Whatsapp application is considered as a replacement for the Short Message Service (SMS) system on the message sender application. The only difference is that SMS uses regular credit, while Line and Whatsapp applications use internet connectivity. Just like Whatsapp, Line application also offers some features: having private and group conversations, sending videos and photos, and interacting through live streaming video.

In addition, Facebook is no longer the most favorite application among students. This can be seen from only $69 \%$ of students who have this application. Indeed, at the beginning of its launching, Facebook application was once the belle of social media to shift Friendster's superiority as one of the pioneers of social media (Ammirati, 2016). However, over time, applications that become Facebook compatriots are appearing more and more so that its prestige is not similar to what it used to be. Even so, Facebook is still a quite popular social media (Soraya \& Husna, 2020).

Furthermore, the duration of using social media in a day based on the indicators of survey results revealed this following thing. If it is assumed that the formal activities of students are as much as 6 hours for studying and 8 hours for sleeping with a total of 14 hours for those two activities, it means that they have 10 hours of free time (excluding studying and sleeping at night). Consequently, around $43 \%$ of students save 5-2 hours without social media in a day, $25 \%$ of students keep 13-10 hours without social media in a day, $25 \%$ have 1 hour a day until they take 2 hours of sleep and lecture, and about $7 \%$ spend their studying and sleeping time up to 3-5 hours a day just to explore social media. Therefore, it can be concluded that only $25 \%$ of students who do not spend their free time for exploring the social media, while most of them spend their free time on social media. In addition, the results of this survey indicate that it is possible for students to access social media while college activities are taking place, or even, they are willing to stay up late for that (Gero et al., 2019; Mutawakkil \& Nuraedah, 2019; Sari et al., 2017).

The survey results of social media usage which appeared in a form of reading activity will certainly affect reading comprehension. The results of statistical calculations using simple linear regression equations show that at moderate levels of social media use, a simple linear regression equation is obtained between the activities of using social media as variable $\mathrm{X}$ and the ability to read as variable $\mathrm{Y}$. This regression equation can be seen from a constant value of 68,945 and the $\mathrm{X}$ coefficient value is -0.004 . The presence of a negative sign on the coefficient $\mathrm{X}$ indicates that the regression is negative. This means that for every increase in one score of social media usage activities, reading comprehension will decrease by $68,945-0,004(1)=68,896$, or for every $1 \%$ increase in social media usage activities, reading comprehension will decrease by 0.004 . In other words, every student whose activity on social media increases, the ability to read will decrease even though in a low significance (low probability). This result is relevant to the opinion of Setiawan and Khamadi (2019) that the habit of doing activities with electronic media, such as gadgets can reduce literacy.

The low significance of the correlation of social media activities with low reading ability is certainly influenced by some varied factors of students' reading activities on social media. The results of the low significance as described above occurred due to the activities of students in using social media in moderate category. Therefore, different research results will still occur when the samples used (students) are on different test results (Azwar, 2005).

The results of the regression equation and hypothesis testing show that there is no effect between the use of social media activities, especially reading activities on social media and the ability to comprehend a reading text. In fact, based on the regression equation result, social media activities and the ability to comprehend reading text contain negative regression. The higher the activity on social media, the lower the ability to comprehend reading text, up to an insignificant level. 


\section{CONCLUSION}

Activities of using social media among students are varied from Instagram, Whatsapp, Line, Facebook, Twitter and Ask FM. Activities that can be done by students with these applications are certainly diverse ranging from writing status, reading and sharing news/articles, chatting via chat, playing games, having video calls, discussing, shopping, and etc. The survey results in this research show that social media use activities can be grouped as follows: $32 \%$ of the social media use activities are very high, $43 \%$ are high, and low media use activity is only $25 \%$, which is between

\section{REFERENCES}

Ammirati, S. (2016). The Science of Growth: How Facebook Beat Friendster--and how Nine Other Startups Left the Rest in the Dust. St. Martin's Press.

Arikunto, S. (2010). Prosedur Penelitian: Suatu Pendekatan Praktik. Jakarta: Rieka Cipta.

Azeharie, S. (2016). Analisis Penggunaan Twitter Sebagai Media Komunikasi Selebritis di Jakarta. Jurnal Komunikasi, 6(2): 83-98.

Azwar, S. (2005). Signifikan atau Sangat Signifikan. Buletin Psikologi, 13(1): 38-44.

Bhattacharjee, S. D., Tolone, W. J., \& Paranjape, V. S. (2019). Identifying Malicious Social Media Contents Using Multi-view Context-aware Active Learning. Future Generation Computer Systems, 100, 365-379.

Cassidy, D. J., Mullen, J. T., Gee, D. W., Joshi, A. R., Klingensmith, M. E., Petrusa, E., \& Phitayakorn, R. (2020). \# SurgEdVidz: Using Social Media to Create a Supplemental Video-Based Surgery Didactic Curriculum. Journal of Surgical Research.

Chrismanto, A. R., \& Lukito, Y. (2017). Klasifikasi Komentar Spam Pada Instagram Berbahasa Indonesia Menggunakan K-Nn. In Seminar Nasional Teknologi Informasi Kesehatan (SNATIK) 2017.

Church, K., \& De Oliveira, R. (2013). What's up with WhatsApp? Comparing Mobile Instant Messaging Behaviors with Traditional SMS. In Proceedings of the 15th International Conference on Human-computer Interaction with Mobile Devices and Services (pp. 352361).

Dewi, A. M. (2018). Pengaruh Iklan Online Melalui Instagram Terhadap Keputusan Pembelian bagi Peningkatan Penjualan Produk Kuliner Lokal. Jurnal Ekonomi Universitas Kadika, 3(1).
1-4 hours. It means that there are $75 \%$ of students whose duration in using social media per day falls on high category, some even reaching 13-15 hours per day.

In relation to the high use of social media, the finding shows that the use of social media activities does not affect the students' reading comprehension. In addition, the higher the activity on social media, the ability to comprehend reading text will decrease. The reduced ability to comprehend reading text is still at an insignificant level that is influenced by many factors, such as the quantity of reading, the types of reading, and the media used when reading.

Endri, K. (2017). Renik Media Sosial. Jakarta: Hadila.

Gero, S., Son, M. M., Prasetya, P. A., \& Selkioma, S. (2019). Pengendalian Diri Mahasiswa Keperawatan Menghadapi Kecanduan Bermain Game Online: Studi Fenomenologi. Prosiding Semnas Sanitasi, 276-285.

Hidayat, M. T., Rosyadi, A., Razak, A. F., Hidayat, M. L., \& Kurniawan, Y. (2019). Fanpage Griya Muda: Dapatkah Popular di Kalangan Mahasiswa Pendidikan Guru Sekolah Dasar? Proceeding of The URECOL, 274-282.

Hindman (2009). Cable TV and Internet Deals.

Indriastuti, N. R. (2019, September). Internet sebagai Sumber Belajar Reading Mahasiswa Prodi Pendidikan Bahasa Inggris Umpo. In Seminar $\mathrm{Na}$ sional Pendidikan dan Pembelajaran 2019 (pp. 400-405).

Lee, J., Lapira, E., Bagheri, B., Kao, H. (2013) Recent Advances and Trends in Predictive Manufacturing System in Big Data Environment

Mao, J. (2014). Social Media for Learning: A Mixed Methods Study on High School Students' Technology Affordances and Perspectives. Computers in Human Behavior, 33: 213-223.

Martini, A. (2019). Penggunaan Media Reading Box untuk Meningkatkan Aktivitas dan Kemampuan Membaca Pemahaman Teks Cerita Anak pada Membaca Intensif (Penelitian Tindakan Kelas pada Siswa Kelas III SDN Dayeuhluhur Kecamatan Ganeas Kabupaten Sumedang Tahun Pelajaran 2017/2018). Jurnal Edukasi Sebelas April, 2(2).

Media Planning Guide Indonesia (2010). An Essential Tool for Every Body Working in or with, the Media in Indonesia, First Edition. Jakarta: Perception Media International.

Meinawati, E., \& Baron, R. (2019). Media Sosial Dan Pembelajaran: Studi Efektivitas Penggunaan 
Facebook dalam Pembelajaran Bahasa Inggris. Jurnal Tatsqif, 17(1): 34-51.

Miranda, S., \& Lubis, E. E. (2017). Pengaruh Instagram sebagai Media Online Shopping Fashion Terhadap Perilaku Konsumtif Mahasiswi Fakultas Ilmu Sosial dan Ilmu Politik Universitas Riau. Riau: Universitas Negeri Riau.

Moghavvemi, S., Sulaiman, A., Jaafar, N. I., \& Kasem, N. (2018). Social Media as a Complementary Learning Tool for Teaching and Learning: The Case of Youtube. The International Journal of Management Education, 16(1): 37-42.

Munzir, A. A. (2019). Beragam Peran Media Sosial dalam Dunia Politik di Indonesia. JPPUMA Jurnal Ilmu Pemerintahan dan Sosial Politik Universitas Medan Area, 7(2): 173-182.

Mutawakkil, M., \& Nuraedah, N. (2019). Gaya Komunikasi Dosen dalam Pembelajaran Mahasiswa. Communicatus: Jurnal Ilmu komunikasi, 3(2): 25-42.

Poerwanti, E. (2008). Assesmen Pembelajaran SD. Jakarta: Dirjen Dikti Depdiknas.

Rasul, N., Rahim, S. A., \& Salman, A. (2015). Penggunaan Media, Norma Kewarganegaraan dan Partisipasi Politik dalam Era Transisi ke Demokrasi di Indonesia. Jurnal Komunikasi: Malaysian Journal of Communication, 31(1).

Sari, M. I., Lisiswanti, R., \& Oktafany, O. (2017). Manajemen Waktu pada Mahasiswa: Studi Kualitatif pada Mahasiswa Kedokteran Universitas Lampung. Jurnal Kedokteran Universitas Lampung, 1(3): 525-529.

Setiawan, A., \& Khamadi, K. (2019). Peran Media dan Teknologi dalam Literasi Visual Seni dan Desain. Prosiding SNST Fakultas Teknik, 1(1).

Sherlyanita, A. K., \& Rakhmawati, N. A. (2016). Pengaruh dan Pola Aktivitas Penggunaan Internet serta Media Sosial pada siswa SMPN 52 Surabaya. Journal of Information Systems Engineering and Business Intelligence, 2(1): 17-22.
Siswati, S. (2012). Minat Membaca pada Mahasiswa (Studi Deskriptif pada Mahasiswa Fakultas Psikologi UNDIP Semester I). Jurnal Psikologi, 8(2): 124-134.

Somadayo, S. (2016). Pengaruh Model Pembelajaran Pqrst Terhadap Kemampuan Membaca Pemahaman Ditinjau dari Minat Baca. Edukasi, 13(1).

Soraya, Y., \& Husna, J. (2020). Motivasi Relawan Melalui Media Sosial Facebook Pada Gerakan Donasi Motor Pustaka di Desa Pematang Pasir Kecamatan Ketapang Kabupaten Lampung Selatan. Jurnal Ilmu Perpustakaan, 8(2): 256266.

Sugiyono (2012). Metode Penelitian Kuantitatif, Kualitatif dan R\&D. Bandung: Alfabeta.

Susanti, H. A. (2015). Strategi Komunikasi Badan Kependudukan dan Keluarga Berencana Nasional (BKKBN). Jurnal ASPIKOM, 2(4): 243254.

Susanto, E. H. (2011). Media Baru, Kebebasan Informasi dan Demokrasi di Kalangan Generasi Muda. Karya Ilmiah Dosen, 1-19.

van Bommel, J., Randahl, A. C., Liljekvist, Y., \& Ruthven, K. (2020). Tracing Teachers' Transformation of Knowledge in Social Media. Teaching and Teacher Education, 87, 102958.

Yanti, P.G., dan Ibrahim, N. (2020). Hubungan Tingkat Pemahaman Membaca dengan Aktivitas Penggunaan Media Sosial Mahasiswa. Jakarta: UHAMKA.

Yanuarti, E., \& Sari, D. P. (2019). Peran Dosen dalam Memanfaatkan Media Sosial sebagai Sarana Literasi Pembelajaran Mahasiswa. JOEAI (Journal of Education and Instruction), 2(2): 127-138.

Yu, R. P. (2016). The Relationship between Passive and Active Non-political Social Media Use and Political Expression on Facebook and Twitter. Computers in Human Behavior, 58: 413420. 